\title{
SHEILA FITZPATRICK
}

\section{Culture and Politics Under Stalin: A Reappraisal}

Much is known about Soviet cultural life under Stalin. It has been described in a large memoir literature which, whether published in the Soviet Union or the West, basically expresses the viewpoint of the old Russian intelligentsia and tends to be a literature of moral protest, either against the Soviet regime as such or against the abuses of the Stalin period. There is an equally impressive body of Western scholarly literature analyzing the syndrome of "totalitarian control" of culture, with its characteristics of arbitrary repression, destruction of traditional associations, enforced conformity, censorship, political controls, and injunctions to writers and artists to act as "engineers of the human soul" in the Communist transformation of society. The concept of totalitarianism-developed in the postwar years, which were also the formative years of American Soviet studies-incorporated its own element of moral condemnation, making the scholarly literature strikingly similar in tone to the memoir literature of the intelligentsia. ${ }^{1}$

The impact of the zhdanovshchina, both on scholars and memoirists, was enormous. The totalitarian model is, in fact, primarily a model of the late Stalin period (1946-53), at least as far as culture is concerned. Zhdanov's bullying of the cultural intelligentsia, the enthronement of Lysenko and the outlawing of genetics, the rhetoric on the transformation of nature and remaking of man, the arrest of Russians who had been in contact with foreigners during the war, the extravagant adulation of Stalin, even the murals in the Moscow metro and the wedding-cake architecture of the new Soviet skyscrapers-all this was the stuff of nightmares for Western intellectuals and the old Russian intelligentsia, the imagery of Orwell's 1984, and the primary data which went into the making of the totalitarian model. Once the concept of "full totalitarianism" had been established for the

1. The categories of scholarly and memoir literature overlap in a number of works which have influenced Western thinking about Soviet culture under Stalin, for example Max Eastman, Artists in Uniform (New York, 1934); Andrey V. Olkhovsky, Music under the Soviet: The Agony of an Art (New York: Praeger, 1955); Iu. Elagin [J. Jelagin], Ukroshchenie iskusstv (New York: Chekhov Publishing House, 1952); Konstantin F. Shteppa, Russian Historians and the Soviet State (New Brunswick, N.J.: Rutgers University Press, 1962). 
period 1946-53, the previous years of Soviet power were interpreted accordingly as development toward totalitarianism. Cultural history became a series of milestones from Lenin's 1905 article on party literature to zhdanovshchina.

Scholars offered various explanations for developments in the culture/ politics relationship in the Stalin period, but all of them emphasized the party's drive for total control and Stalin's personal drive for total power and absolute authority. The party controlled culture and Stalin controlled the party. Involved in this interpretation were a number of specific propositions and assumptions, among which were (1) that the party assumed responsibility for guiding, and if necessary forcing, scholarship and the arts in certain directions, generally directions suggested by ideology; (2) that Stalin required an identifiable "party line" on all cultural questions, and thereby excluded the possibility of fundamental debate within the cultural professions; (3) that the Stalinist party rejected even the limited concepts of professional autonomy and academic and artistic freedom which had been accepted under NEP, and by imposing total control deprived cultural institutions and professional organizations of all powers of initiative and negotiation; (4) that, as a consequence, there was a "we-they" relationship between the cultural intelligentsia and the party, with the party strivingusually successfully - to infuse its values into the intelligentsia.

This interpretation would not have gained general credence among Western scholars had it not in many respects corresponded to reality. Nevertheless, as we look carefully at the Stalin period, there are many aspects of the interpretation which seem open to question, or at least to require qualification and definition. In the first place, the party/culture relationship described in the totalitarian model is, at best, an ideal type toward which the Soviet Union may have been evolving at the end of Stalin's lifeor may not have been. Even in the postwar period, the situation was not uniformly restrictive; and the tendency of policy in the last years (1950-52) was in many respects ambiguous. But the postwar years, however we interpret them, represent only a small fraction of the whole Stalin period. Perhaps these years give us the summation of "Stalinism," but the assumption that this must be so comes from the totalitarian model. Historians have usually treated the last decade of Alexander I's reign, after the victory over Napoleon, more as an aberration than a culmination. We should at least consider the possibility of a similar approach to Stalin's rule after the victory over Hitler.

In the second place, the relationship between the party and culture is, in all periods, far more complex than a "we-they" image would suggest. Stalinist cultural policy is not adequately explained by chronicling the instances of Stalin's personal intervention, or even describing the broad "conclusions" 
drawn when Stalin intervened in a specific case. The data here are fragmentary, inconsistent, and, above all, slight. For satisfactory explanations we have to look further, casting a net wide enough to include input from social and professional groups and government institutions, as well as from the Politburo and Stalin himself. If final authority was vested in the party, the party nevertheless delegated, bestowed, or countenanced other types of cultural authority which resided in individuals or cultural institutions. Indeed, the legitimization of cultural policy was often developed not by reference to party doctrine or the pronouncements of party leaders, but by reference to nonparty authority figures with status in their own professions like Gorky, Stanislavsky, and Pavlov or nonparty praktiki like Lysenko and Makarenko. Certainly the political leadership was determined to prevent the arts from posing a political or philosophical challenge, or from depicting reality so starkly that a challenge might be provoked. Yet at the same time, the leadership's attitude toward many established cultural values was more often deferential than destructive. As party values penetrated culture the cultural values of the old intelligentsia were penetrating the party.

It is too soon to present a definitive evaluation of the cultural situation under Stalin, because the Stalin era was marked by strict censorship of information on cultural politics and it remains inhospitable territory-especially in comparison with the period of the October Revolution and the 1920 s-for contemporary Soviet scholars. However, it is possible to make some suggestions toward a reappraisal of the relationship of culture and politics under Stalin and to point to certain problems in the interpretation most widely accepted in the scholarly literature; and that is what this article sets out to do.

One of the explanations for the persistence of the totalitarian model in our interpretations of the Stalin period is that the model is fundamentally ambiguous on one key point. On the one hand, it emphasizes dynamic change: a ruthless, almost heroic, but terrible remaking of man and society, a challenging of accepted societal values, a continuous revolution. On the other hand, it stresses tight central control, ideological rigidity, crushing of experimentation and initiative, and the establishment of the most restrictive political order. In the real world these two images are contradictory, for a major challenge to society and its values is not conducive to the establishment of order. Continuous remaking of society requires the use of local officials and activists who themselves have a strong impulse to challenge accepted norms, and such persons are unlikely to be devoid of personal initiative and totally responsive to instructions from above. What has made the totalitarian model so persuasive is that its dynamic aspect can be used in explaining the First Five-Year Plan period and its rigid aspect in explaining the later 
Stalin period-without our realizing that there has been a basic shift in interpretative ground as, in analyzing the whole Stalin period, we move from one totalitarian model to the other. ${ }^{2}$

Western scholars have labeled the period of the First Five-Year Plan "the Third Revolution," but their descriptions of that revolution have focused almost exclusively on the impact of collectivization and rapid industrialization. It is important to remember that these years were also a period of "cultural revolution," to use the phrase adopted by protagonists at the time. Cultural revolution, ${ }^{3}$ which was at its height in the years 1929-31, was an attack by young Communist militants on the "bourgeois intelligentsia." The initiative came from the party leadership, and probably from Stalin, with the trial of the Shakhty engineers for wrecking and sabotage in 1928. But it was an initiative which the most active participants in the cultural revolution-RAPP (the Communist Association of Proletarian Writers), young scholars in the Communist Academy and the Institute of Red Professors, and the Komsomol leadership-had been insistently demanding for some time. These groups had been preparing themselves for battle against "bourgeois hegemony" in culture without earlier official encouragement (with official discouragement in some cases, as Bukharin's comments on RAPP during the 1924-25 literary discussions indicate ${ }^{4}$ ). NEP was a period of intense cultural factionalism, with organized groups of Communists and antitraditionalists continually at each other's throats, competing for control of journals and institutes, and demanding the exclusive patronage of the State Publishing House, the Commissariat of Enlightenment, and the party Central Committee. During the cultural revolution, Communist groups came close to winning that exclusive patronage. However, they were not Stalin's creatures and owed him no special loyalty, though out of opportunism and some hostility to Bukharin they made their contribution to the 1928-30 campaign against the party "Right Opposition."

2. The "two image" analysis of the totalitarian model is made by Jerry F. Hough in "Cultural Revolution in Historical Perspective," to be published in Sheila Fitzpatrick, ed., Cultural Revolution in Russia, 1928-1931.

3. Various aspects of the cultural revolution are discussed in $\mathrm{E}$. J. Brown, The Proletarian Episode in Russian Literature, 1928-1932 (New York: Columbia University Press, 1953) ; David Joravsky, Sovict Marxism and Natural Science, 1917-1932 (New York: Columbia University Press, 1961); and Loren R. Graham, The Soviet Acadomy of Sciences and the Communist Party, 1927-1932 (Princeton: Princeton University Press, 1967). On the phenomenon as a whole, see Sheila Fitzpatrick, "Cultural Revolution in Russia, 1928-32," Journal of Contemporary History, 9, no. 1 (1974), and the forthcoming volume of essays edited by Sheila Fitzpatrick, Cultural Revolution in Russia, 19281931.

4. See Bukharin's speech to a meeting called by the press department of the Central Committee in May 1924, in $K$ voprosu o politike $R K P(b)$ v khudozhestvennoi literature (Moscow, 1924). 
The First Five-Year Plan was a time of great tribulation for the old intelligentsia. With Lunacharskii's departure from the Russian Commissariat of Enlightenment in September 1929, that institution lost the will and power to offer protection to the old cultural intelligentsia, and the same was true of such major employers of bourgeois technical specialists as Gosplan and Vesenkha. Young Communists took over the direction of scholarly institutes and journals. Nonparty writers were often unable to publish. Nonparty professors had to stand for "reelection" by their students, and nonparty engineers were imprisoned for anti-Soviet activity (a charge often based only on failure to fulfill impossible targets set by the First Five-Year Plan).

But for young Communists it was a time of unprecedented opportunity. They provided much of the real enthusiasm behind the rhetoric of transforming nature, creating the New Man and "catching up and overtaking" the industrialized West, which was characteristic of the period. In concrete terms, they had the opportunity to move upward into responsible jobs. This was true not only of young Communists but (despite the priority given to Communists and proletarians) of all young people with an education; and it was also true of skilled workers, who were drafted in large numbers into higher education, management, and administration. A new "proletarian intelligentsia"-mainly young, and a substantial proportion genuinely workingclass or peasant in origin-was being forced through a vastly expanded system of technical and higher education at breakneck speed. ${ }^{5}$

Like all revolutions, the cultural revolution produced disorder. The "cultural army"-as the Komsomol called its corps of cultural revolutionaries-inclined toward partizanshchina rather than soldierly discipline, and the militant Communist intellectuals were flagrantly guilty of sektanstvo and gruppovshchina. The collapse of established authorities brought "hare-brained schemers" to the fore, even in such normally pedestrian areas as labor training and technical education. The education system, which had simultaneously undergone great expansion and radical structural reorganization, was in chaos. Inevitably, the aftermath of revolution brought policies intended to restore order, discipline, and authority in the cultural sphere.

The first step was taken in mid-1931, when bourgeois engineers-the former "wreckers and saboteurs"- -were welcomed back into the Soviet fold by Stalin. ${ }^{6}$ It was acknowledged that radical restructuring of the technical education system, "shock tempos" for the training of proletarian engineers

5. For quantitative growth in the period 1928-33, see Sotsialisticheskoe stroitel'stvo: Statistichcskii ezhegodnik (Moscow: TsUNKhU Gosplana SSSR, 1934), p. 406; for changes in social composition of the student body, together with a breakdown by sex and party membership, see ibid., p. 410.

6. Speech of June 23, 1931 in I. V. Stalin, Sochineniia, vol. 13 (Moscow, 1951), pp. 69-73. 
and technicians, and harassment of the old technical intelligentsia had had a negative impact on industrial efficiency; and an All-Union Committee headed by Krzhizhanovskii, the former president of Gosplan, was set up to repair the damage. ${ }^{7}$ In this area, the impetus for reorganization seems to have come from Ordzhonikidze's Commissariat of Heavy Industry (the successor to Vesenkha), whose primary interest was clearly in maximum industrial efficiency and use of competent specialists regardless of their class origin or party status. Bukharin, Stalin's defeated opponent, was one of the Commissariat's main spokesmen on the need to conciliate the old technical intelligentsia. ${ }^{8}$ Measures for reorganization of the technical education system were drafted by "bourgeois" professors and engineers acting as government consultants-and they were uninhibited in expressing their scorn for Communist officials and industrial managers who had meddled in academic and technical matters beyond their understanding, and for the ill-prepared proletarian and Communist students who had been pushed through higher technical school during the First Five-Year Plan. ${ }^{9}$

Shortly after Stalin's statement of June 1931 on the bourgeois engineers, the Central Committee of the party issued a resolution denouncing the theory (propounded by some of the more extreme, but temporarily influential, Communist cultural revolutionaries on the education front) of "the withering away of the school." It was the first in a long series of resolutions ${ }^{10}$ through which the Central Committee attempted to restore discipline, orderly procedures, and traditional teaching methods in the schools. Timasheff ${ }^{11}$ has

7. Resolution of TsIK and SNK SSSR of September 15, 1933, and "Statute on the All-Union Committee on Technical Education under TsIK SSSR," Presidium of TsIK, October 17, 1933, in Vsesoiuznyi komitet po vysshemu tekhnicheskomu obrazovaniiu pri TsIK SSSR, Biulleten', 1933, no. 9-10, p. 7. It is clear from the Biulleten' that the committee began work considerably before its formal establishment, probably some time in 1932.

8. See, for example, Front nauki i tekhniki, 1932, no. 7-8, p. 121; ibid., 1932, no. 10, p. 94 ; ibid., 1932 , no. $11-12$, p. 111.

9. See, for example, articles by Professor A. M. Berkengeim, Professor Ia. N. Shpilrein and S. V. Volynskii in Vysshaia tckhnichcskaia shkola, 1934, no. 1 (September).

10. For the first resolution of the Central Committee, "On the elementary and middle school," September 5, 1931, see KPSS v rezoliutsiiakh i resheniiakh s"esdov, konferentsii $i$ plenumov TsK, vol. 4 (Moscow, 1970), p. $569 \mathrm{ff}$. (in this edition, the date of the resolution is wrongly given as August 25, 1931). For subsequent resolutions of the Central Committee-"On teaching programs and regimes in the elementary and middle school" (August 25, 1932), "On textbooks for the elementary and middle school" (February 12,1933), "On the structure of the elementary and middle school in the USSR" (May 1934), "On publication and sale of textbooks for the elementary, incomplete middle, and middle school" (August 7, 1935), and "On the organization of teaching work and internal discipline in the elementary, incomplete middle, and middle school" (September 3, 1935) - see Direktivy $V K P(b)$ i postanovleniia sovetskogo pravitel'stva $o$ narodnom obrazovanii, vol. 1 (Moscow-Leningrad, 1947), p. $159 \mathrm{ff}$.

11. Nicholas S. Timasheff, The Great Retreat: The Grozuth and Decline of Communism in Russia (New York: E. P. Dutton, 1946). 
characterized this as "the great retreat." It was retreat, but the starting point was almost as far out on the axis of anarchic experimentation as it was possible to go, and the official line of the early 1930s that "life itself" had discredited the educational innovators was not far from the truth. Confronted with ineffective teaching in the schools, organizational chaos, protests from teachers and parents, and mutual accusations of political deviation among the educationalists themselves, the party leadership decided to seek safer ground. Its resolutions aimed to establish, in place of the unpopular progressive school, a disciplined school with formal procedures and academic orientation-the kind of school, in fact, which teachers and white-collar parents and ambitious lower-class parents had wanted for the past decade.

Social discrimination in educational enrollment had been practiced to some extent in the 1920s and reached its height during the cultural revolution. It was a cumbersome process which became harder to justify as the number of school and university places increased. There was, moreover, no possible way of conciliating the old intelligentsia without giving its children access to academic secondary and higher education. Thus in the first half of the 1930s, while large numbers of proletarian and peasant children remained in secondary and higher schools, the policy of forcing them in and other children out was gradually abandoned, ${ }^{12}$ not to be revived even in moderate form until the days of Khrushchev. The constitution of 1936 proclaimed the equality of all citizens regardless of class. The distinction between "bourgeois intelligentsia" and "Red specialists" was dropped, and Stalin began to speak of a new classless "Soviet intelligentsia." "13

In this process, the old cultural intelligentsia was an equal beneficiary with the old technical intelligentsia. The rise in status of the "bourgeois" cultural intelligentsia followed the fall of the "proletarian" makers of cultural revolution. In 1931-32 the party leadership had clearly indicated its impatience with Communist scholasticism, ${ }^{14}$ Communist "hare-brained scheming," 15 and local Communist dictatorships in the arts and scholarly disciplines which were unpopular, unproductive, and insubordinate to Central Committee authority. Some of the Communist intellectuals-for example, Averbakh, the

12. Discrimination on grounds of social origin in university admission was formally dropped at the end of 1935 . See Direktivy $V K P(b)$ i postanovleniia sovetskogo pravitel'stva o narodnom obrazovanii, vol. 2, p. 89. 364-66.

13. Stalin, Sochineniia, ed. Robert H. McNeal, vol. 1 (14) (Stanford, 1967), pp.

14. See Stalin's letter to the editors of Proletarskaia revoliutsiia, "On some questions of the history of Bolshevism," in Proletarskaia revoliutsiia, 1931, no. 6; and Stalin, Sochineniia, vol. 13, pp. 84-102.

15. See the attack on Shulgin's theory of "the withering away of the school" in the Central Committee resolution "On the elementary and middle school," cited in footnote 10 , above. 
leader of RAPP-were too ambitious; others were suspected of involvement in anti-Stalin maneuvering in the so-called "left-right bloc."16 They lacked the humility which nonparty status bestowed; and perhaps, although this seems far-fetched, they did represent some potential political threat to Stalin. A great many of the former cultural revolutionaries were arrested in the purges; some, including Averbakh and associates, were publicly denounced as Trotskyite traitors. ${ }^{17}$

When the period of "proletarian hegemony" ended in 1932 with the dissolution of RAPP, ${ }^{18}$ a decision was made to organize an all-inclusive Union of Soviet Writers in which literary factions would be dissolved and "bourgeois" non-Communists admitted on equal terms with the Communists. Even the bourgeois avant-gardists, whose reputations as troublemakers almost rivaled that of the proletarians, were admitted and for a few years not attacked. The formula of "socialist realism" which the Union adopted was not originally conceived as a "party line," any more than the Union was conceived as an instrument of total party control over literature. Both were initially intended to cancel out the old RAPP line of proletarian and Communist exclusiveness and make room for literary diversity-their disciplinary uses came later, with the mounting political tension of 1935-36.

The writer Maxim Gorky, who returned permanently to the USSR in 1931, played a central role in the literary reorganization. Having left Russia in the early 1920s after disagreements with Lenin on the October Revolution and the treatment of the intelligentsia during the Civil War, Gorky returned to be honored by Stalin and to provide a symbol of reconciliation. Gorky was a stranger to the new generation of Communist intellectuals who had achieved prominence during his absence (and RAPP, for example, was notably unenthusiastic about his prospective return, which was anticipated from 1928), but he was an old friend and patron of such leading "bourgeois" figures as the scientist Ivan Pavlov, the theater producer Stanislavsky, and the grand old men of the Academy of Sciences. His return was followed by

16. Many examples of Averbakh's ambition and insubordination are given in a valuable Soviet monograph by S. Sheshukov, Neistovye revniteli: $I z$ istorii literaturnoi bor'by 20-kh godov (Moscow: Moskovskii rabochii, 1970). On the "left-right" bloc, see resolution of the Central Committee and Central Control Commission of December 1, 1930, "On the fractional work of Syrtsov, Lominadze and others," Pravda, December 2, 1930; and Literatura $i$ iskusstvo, 1930, no. 2, p. 3 (editorial on involvement of Communist Academy members).

17. For accusations against RAPPists Averbakh and Kirshon, see Literaturnaia gazeta, April 20, 1937. It should be noted that Averbakh actually had been a Trotskyite in 1923-24 and the playwright Kirshon, his close friend, was related by marriage to Iagoda.

18. See Central Committee resolution "On the reconstruction of the literary-artistic organizations" of April 23, 1932, translated in E. J. Brown, The Proletarian Episode in Russian Literature. 
a rapid rise in the fortunes of all of these. The Academy of Sciences-still the stronghold of traditional scholarship, despite the much resented election of Communists like Lunacharskii and Bukharin as academicians in 1929-3019recovered a position of honor, and after a few years absorbed most of the institutes of the Communist Academy.

The reconciliation was not a temporary or purely declarative one. From the early 1930s until the end of the Stalin period, part of the old cultural intelligentsia and most of the preeminent prerevolutionary cultural institutions (the Academy of Sciences, Moscow University, the Bolshoi Theater and its opera and ballet companies, the Moscow Arts Theater, and so on) enjoyed the special favor of the Soviet government and the Communist Party. The intellectuals and the institutions were, of course, subject to censorship, and Communist administrators were appointed to the institutions. This, however, did not make the institutions Communist. In contrast to the situation during the cultural revolution and indeed throughout NEP, they were not prevented from cultivating a dedicated apolitical professionalism-almost the spirit of a self-contained, privileged, and exclusive caste-provided they followed some ritual observances of respect for the regime and avoided political or social comment. Eminent cultural and scientific figures were not forced to become Communists, and in the 1930s few of them did so. (Even Lysenko and Makarenko, who were outsiders in their professions seeking recognition, did not find it necessary to join the party.) Within the mass of the "new Soviet intelligentsia," an old cultural intelligentsia, of bourgeois demeanor and largely unreconstructed anti-Communist habits of mind, was allowed to retain its separate identity and even, through teaching and example, perpetuate itself in the younger generation.

This reconciliation, because it lacked practical or utilitarian justification, was unlike the reconciliation with the technical intelligentsia. The cultural reconciliation was a luxury investment, involving self-imposed limitation of Communist ideological influence. Even assuming conscious intention on the part of the leaclership to dazzle the Soviet people with circuses in a time of bread rationing and to impress the West with Soviet kul'turnost', the choice remains remarkable. It is difficult to avoid the conclusion-noting the numerous instances of Stalin's personal intervention in the fate of prestigious apolitical poets, his consultations with bourgeois scholars on matters of mutual academic interest, his derogatory comments on Communist literati, and the competitive anxiety of other party leaders to demonstrate that they too were on visiting terms with the great non-Communist writer Maxim Gorky-that the leadership respected "real

19. See Loren R. Graham, The Soviet Academy of Sciences and the Communist Party, 1927-1932. 
culture" and was inwardly convinced that it was to be found among nonproletarians and non-Communists.

This was a period of straitened resources, when industrialization and military preparation were urgent investment priorities, yet the Soviet state supported culture on a lavish scale. From the first half of the 1930s, the intelligentsia-Communist and nonparty, technical and cultural-became an unambiguously privileged group within the society. ${ }^{20}$ Privilege was expressed in salaries, access to special stores and resorts, housing priority, children's access to higher education, honors, and awards. These were essentially the same privileges offered to the upper levels of bureaucracy, the military, security police, and industrial management. Within all these groups there were hierarchies of privilege, but basic privileged status was obtained through possession of formal credentials such as union membership and academic position-in other words, it was normally conferred on an individual by the profession and not by the party. No distinctions were drawn between branches of the intelligentsia on the grounds of their relative utility to the state, but there were distinctions based on the traditional social status of various groups. Thus, engineers and opera singers were highly privileged, while those in the useful but traditionally low-status occupations of librarian and schoolteacher were not.

Established cultural institutions were subsidized on a much more generous scale than under NEP, and they had an honorable place in the grandiose plan for the rebuilding of Moscow prepared under Kaganovich's supervision. The first major repairs of their buildings since the Revolution were undertaken in the 1930s. The Academy of Sciences, which was moved from Leningrad to Moscow in the mid-1930s, got new buildings including those originally intended for the Communist Academy. The climax came in the last years of Stalin's rule with the building of a Stalinist-baroque palace on Lenin Hills for Moscow University-an institution largely devoted to the humanities and pure sciences, which during the cultural revolution had been treated as an almost useless "survival of the past" and temporarily dissolved as a corporate entity. ${ }^{21}$

It is well known that under Stalin the cultural intelligentsia was subject to the constant harassment of censorship. No cultural figure, no matter how distinguished, was exempt from the possibility of having his books or films banned, exhibitions canceled, or theatrical productions closed after one performance, although in normal circumstances, "connections" in the party leader-

20. On the privileges, see Moshe Lewin, "Society and the Stalinist State in the Period of the Five-Year Plans," Social History, no. 2 (May 1976), pp. 171-72; and Elagin, Ukroshchenie iskusstv, pp. 286-90.

21. See Moskovskii universitet za 50 let sovetskoi vlasti (Moscow: Moskovskii universitet, 1967), pp. 68-69. 
ship and bureaucracy offered some protection. Even Fadeev, the powerful secretary of the Writers' Union in the 1940s, who was a longstanding party member, had to rewrite his novel Molodaia gvardiia and apologize for its original faults. ${ }^{22}$ But this does not change the basic situation of the cultural intelligentsia as a highly privileged group within the society. Successful film directors, writers, actors of the Moscow theaters, and concert violinists enjoyed great prestige and reaped enormous material benefits. Jelagin (a musician in the Vakhtangov Theater orchestra during the 1930s) compares their status with that of the aviators and Polar explorers whose exploits were celebrated almost daily in the press. He even clains that the banners carried by alternating columns of children in the Revolution Day procession of 1937 read "We want to be aviators" and "We want to be violinists." 23

Artists at the top of their profession had access to the highest Soviet elite. Biographers of the party leader Kuibyshev, for example, note the friendship that developed between him and Gorky through the proximity of their dachas; and also list, as a matter of course, the writers and artists of somewhat lesser status with whom Kuibyshev had social contact. ${ }^{24}$ Patronage and social relations were closely, though not necessarily, linked. Stalin himself sometimes acted as a patron, for example, in arranging a job for the playwright Bulgakov at the Moscow Arts Theater. Bukharin, who is reported by Nadezhda Mandelstam to have been a patron of her husband in the early 1930s, was also an amateur painter whose work was exhibited in Moscow until 1936. Enukidze of the Central Committee secretariat in the prepurge period was well known as a patron of the cultural intelligentsia and, like the amateur opera singer Voroshilov, had a particular interest in the Bolshoi Opera. ${ }^{25}$ (We have less information on patronage during the postwar period, but attacks on writers' reliance on patronage and protektsiia in the $1940 \mathrm{~s}^{26}$ suggest that the phenomenon persisted.)

Party leaders, GPU/NKVD chiefs, and top military personnel faithfully attended premieres at the Moscow Arts and Vakhtangov Theaters, the Meyerhold Theater, and the Bolshoi Opera and Baliet. They were habitués of the salons of Zinaida Raikh (Meyerhold's wife) and Natalia Sats (niece by marriage of Lunacharskii, director of the Moscow Children's Theater, and

22. Harold Swayze, Political Control of Literature in the USSR, 1946-1959 (Cambridge, Mass.: Harvard University Press, 1962), pp. 45-47.

23. Elagin, Ukroshchenie iskusstv, p. 303.

24. G. V. Kuibysheva, O. A. Lezhava, N. V. Nelidov, and A. F. Khavin, Valerian Vladimirovich Kuibyshev (Moscow, 1966), p. 352.

25. These examples belong to the folk history of the Moscow intelligentsia and are by their nature difficult to document. The Mandelstam case is reported in Nadezhda Mandelstam, Hope against Hope (New York: Atheneum, 1970); the Bulgakov case in E. Proffer, ed., The Early Plays of Mikhail Bulgakov (Bloomington and London: Indiana University Press, [1972]), pp. xviii-xx.

26. Swayze, Political Control, p. 40. 
an intimate of Tukhachevskii); they attended the luxurious supper parties of the nonparty writer Count Aleksei Tolstoi-with Gorky and the aircraft designer Tupolev, one of the three Soviet citizens rumored to have inexhaustible and self-renewing accounts at the State Bank. ${ }^{27}$

The 1930s, in other words, saw the formation of a Soviet "high society" in which the artistic intelligentsia mingled with the top nachal'stvo. The intelligentsia was not simply providing jesters for the Stalinist court, though that was part of it. It provided kul'turnost', which was becoming a mark of status in the society. Although the Soviet Union, after 1938, had a governing elite that was, in large part, technically educated and professionally experienced in industry, the political leaders did not choose a similar route for their children. Children of the elite must be "cultured." Thus, the tendency was to send sons to diplomatic training schools, military academies, institutes of journalism, or prestigious nontechnical schools like the philological and physical-mathematical faculties of Moscow University, and daughters to institutes of literature, journalism, music, and ballet. ${ }^{28}$ The middle ranks of society followed the pattern of the elite. Factory managers and local party secretaries-themselves products of technical and party schools-acknowledged the social imperatives of upward mobility by having their daughters take singing lessons and their sons study foreign languages, mathematics, and pure science. ${ }^{29}$

Western and Soviet scholars alike have assumed that the party's primary interest in the cultural field was inculcation of Marxist and Communist values. However, as the foregoing discussion suggests, inculcation of values was at least a two-way process. Western scholarship has been based on the further assumption that the party aimed at direct, total control of culture through the enforcement of orthodoxy. But what were the orthodoxies to which the intelligentsia had to conform?

The party required acknowledgment of the insights of Marxism-Leninism in social science works, applied the criterion of partiinost to the work

27. Elagin, Ukroshchenie iskusstv, p. 143.

28. A partial list-unreliable, because it is based on information obtained in interviews and from various memoir sources-of the education and professions of children of the political elite would include Stalin's younger son and daughter-air force and literature; Molotov's daughter-Gnesin Musical Institute; Litvinov's son and daughter-science and literature; Zhdanov's son-science and scientific administrative work in Central Committee apparat; a Kamenev son-air force cadet; Lunacharskii's son and daughter -both journalism, after higher education respectively in literature and science; Khrushchev's daughter-science journalism; Kosygin's daughter-foreign languages.

29. For illustration, see Lena and family in the Stalin Prize-winning novel by Iurii Trifonov, Studenty (Moscow: Molodaia gvardiia, 1951). On meshchanskaia kul'turnost', see Vera S. Dunham, "The Uses of Stalinist Literary Debris," Slavic Review, 32, no. 1 (March 1973) : 115-28. 
of Communist intellectuals, and encouraged artistic tributes to Stalin. But even in literature and the social sciences-areas particularly susceptible to political judgment, the criteria and desiderata could provide only limited guidance, as long as the party did not require party membership of the intelligentsia and gave equal or greater honor to cultural figures who were nonparty and non-Marxist.

In most situations, the orthodoxies of immediate practical relevance to the professions were not political. They were local professional orthodoxies, established by a process of interaction between the professions and the party's cultural administrators which was only in a few cases affected by intervention or explicit direction from the party leadership. For a writer, conformity meant respect for Gorky, respect for the Russian classics, emulation of the style of Pushkin or Nekrasov in poetry, Tolstoy in the novel, and so on. In the theater, conformity was enulation of Stanislavsky. For painters, the nineteenth-century peredvizhniki provided the orthodox model; for composers, Tchaikovsky and Rimsky-Korsakov. Orthodoxies were based on cultural authorities, alive or dead, whose work and obiter dicta became the basis of a system beyond reproach or criticism. The orthodoxies could be changed, but only by creative reinterpretation-forgotten aspects of the Gorky legacy, for example, or new insight into Makarenko's educational practice.

Members of the cultural intelligentsia could, of course, commit ideological crimes, just as they could play for high stakes by claiming ideological virtue. But from the late 1930s, theaters were in much more danger of being criticized for anti-Stanislavskian principles than for anti-Marxist ones; geneticists were more likely to be attacked for not understanding Lysenko than for not understanding dialectical materialism; even writers were more likely to offend by flouting Gorky's principles of realism than by misrepresenting the process of socialist transformation in the countryside. In the purges, members of the avant-garde movements of the 1920 s were denounced as "formalists" in 1936 and suffered disproportionately. Analysis of the Letopis' zhurnal'nykh statei for 1937-38 suggests that in dangerous times, when the intelligentsia sought the protection of absolutely reliable authority, the figure they invoked was not Marx, or Lenin, or even Stalin, but Maxim Gorky. ${ }^{30}$ To pay conspicuous tribute to Stalin-by representing his person

30. Between July 1937 and December 1938, Gorky was the subject of 333 scholarly articles listed under litcraturovedenie in the Letopis', or 15 percent of the total. Pushkin, with 220 articles, was in second place. Four articles were published on Marx, Engels, or Marxist literary criticism; 18 on Lenin; 7 on Stalin. The Stalin articles and many of the Lenin ones were on the image of Stalin (Lenin) in folklore, the other Lenin articles being of the "Lenin on Gorky," "Lenin on Belinsky" type. (The first half of 1937 has been omitted from the calculation above because of distortion attributable to the Pushkin centenary: of 840 articles published January-June 1937 on literature, 429 were on Push- 
in plays or films or writing a scholarly work on the history of Bolshevism in the Caucasus, for example-was going beyond the area of normal conformity into an area of high possible reward but extremely high risk.

Cultural authorities, then, had some protective function for the professions. But they also filled a need of the bureaucracy, particularly the censors. Lower-level officials, ignorant of scholarship and the arts, but required to supervise them, needed formal criteria to identify right and wrong. This need was particularly acute from 1935 to 1939 , when officials were simultaneously required to increase vigilance and to discard the old criteria-which rankand-file Communists instinctively understood—of social origin and "class tendency." Orthodoxy by reference to established cultural authorities replaced the earlier orthodoxy of party membership and working-class origin.

Cultural authorities emerged through negotiation between professions, cultural bureaucrats, and, in some cases, the party leadership. In different circumstances, pressures from one or another of these groups predominated. Within the professions, where old factional rivalries were only formally abolished, pressure might come from a "bourgeois" establishment using its connections in the leadership, from Communists of the cultural-revolution generation using their remaining connections, or from a group of enthusiastic professional outsiders who had the good fortune to appeal to official Communist sensibilities. In this article, we can only suggest the complexities and range of possibilities by a brief survey of the major cultural authorities of the Stalin era.

Gorky, ${ }^{31}$ the prototypical cultural authority, received that status on his return to the Soviet Union in 1931, when both the profession and the party leadership were dissatisfied with RAPP and looking for an alternative. He probably would not have returned without leadership assurances that he would have authority without administrative responsibility or party membership. He acted as cultural arbiter, patron-particularly of the nonparty

kin, 68 on Gorky, 2 on Marx and Engels, 4 each on Lenin and Stalin.) In the category of khudozhestvennaia literatura (poems, plays, novels, short stories) published in the journals 1937-38, Stalin was the subject of 121 works (mainly poems by Central Asian and other non-Russian writers and folk balladists), Pushkin the subject of 65 works, Lenin of 62 , and Gorky of 8.

An analysis for comparative purposes of the Letopis' for 1948 (minus two of the weekly issues) shows Gorky still in first place as the subject of 45 articles, or 9 percent of the total, as against 8 on Pushkin, 1 on Marx-Engels, 3 on Lenin, and none on Stalin. In the khudozhestvennaia literatura category for that year, Stalin was the subject of 25 works, Lenin of 10, Gorky of 4, Pushkin of 4, and Marx-Engels of 2.

31. There is a massive Soviet literature on Gorky. Of particular interest for the purposes of this article are L. Bykovtseva, Gor'kii v Moskve, 2nd ed. (Moscow: Sovetskii pisatel", 1966), and Valentina Khodasevich, "Gorky as I knew him," Novyi mir, 1968, no. 3. No adequate study of Gorky's role in the 1930s has been written in the West, though there is a useful short chapter in Boris Thomson, The Premature Revolution (London: Weidenfeld \& Nicolson, 1972), pp. 186-205. 
cultural intelligentsia-and entrepreneur. The definition of "socialist realism" was largely Gorky's, as was the firm establishment, in Soviet ideology, of the concept of a classless and apolitical "classical heritage" in culture. Gorky not only provided the model for nonparty cultural authority, but also brought forward candidates for the position in various professions, among them Stanislavsky, Makarenko, and Pavlov.

Stanislavsky was a pure professional, with a prerevolutionary reputation and no interest in politics or social causes. In the early 1930s, he used Gorky's protection to rehabilitate his Moscow Arts Theater after a decade of criticism by Communist avant-gardists culminating in the onslaughts of RAPP: the theater was styled "imeni Gor'kogo" and staged a series of new productions of Gorky's plays ${ }^{32}$ (which Stanislavsky had also produced before the Revolution). Stanislavsky himself remained aloof, showed no desire to become a Soviet cultural authority, and devoted the last years before his death in 1938 to elaborating his theatrical system, the Stanislavsky method. He emerged as a cultural authority around 1937-38 through no actions of his own and without any formal laying on of hands by Stalin or the Central Committee. The conjunction of circumstances which made him an authority included the disgrace of Meyerhold, the avant-garde and proCommunist director who was Stanislavsky's old rival, and anxiety within the theatrical profession produced by the purges. The new "Stanislavskian orthodoxy" was discussed at a meeting of theater producers held early in $1939,{ }^{33}$ where speakers attributed its existence to the fact that the profession was disoriented by the attacks on Meyerhold-whom many had taken as a model for Communist theater-and to the desire of provincial theaters and censors to have a safe and reliable standard of conformity for selfprotection.

In the development of Makarenko as a cultural authority, we find an extremely rich mixture of professional and institutional interests. Makarenko ${ }^{34}$ was both an educationalist and a writer, a self-educated nonparty man of working class origin who was somewhat hostile to what he saw as the

32. Moskovskii khudozhestvennyi teatr $v$ sovetskuin epokhu: Materialy $i$ dokumenty (Moscow: Iskusstvo, 1962).

33. The stenographic report (excluding Meyerhold's fanous outburst against repression in cultural life) was published in Rezhisser $v$ sovetskom teatre: Materialy pervoi vsesointnoi konferentsii (Moscow-Leningrad: Iskusstvo, 1940). See especially the report by S. M. Mikhoels and subsequent discussion, p. $73 \mathrm{ff}$.

34. The English-Janguage studies of Makarenko as educational theorist shed little light on his literary career or on his emergence as a public figure. A useful Russian source, in addition to the seven-volume Sochincniia published in the 1950s, is N. A. Morozova, A.S. Makarenko: Seminarii (Leningrad: Uchpedgiz, 1961). On the controversy surrounding Makarenko in the late 1930s, I have benefited from the research of a Columbia University graduate student, Gary Davis. 
intellectual establishment in both his chosen professions. In the 1920s, he organized colonies for delinquent children in the Ukraine-first, unhappily, under the republican education commissariat, which he saw as a haven for impractical intellectuals; later under the GPU, whose methods he admired. Gorky visited the GPU children's commune in the late twenties and encouraged Makarenko to write about his experiences. In the early thirties, Gorky helped him publish his first book, Pedagogicheskaia poema. In 1937, after the dissolution of all the GPU children's communes, ${ }^{35}$ Makarenko came to Moscow to seek his fortune as a professional writer.

The Writers' Union admitted him because of Gorky's (now posthumous) approval, but treated hin rather patronizingly as a crude but talented amateur of the Nikolai Ostrovskii (How the Steel zeras Tempered) type. Makarenko's dislike of establishment intellectuals increased. Unlike Stanislavsky, Makarenko wanted and sought authority. He systematized and publicized his educational theories, and collected a group of supporters including Komsomol activists, former RAPPists, and persons earlier associated with the GPU educational network-essentially a Communist group with the ethos of cultural revolution. ${ }^{36}$

The first circumstances that aided Makarenko's achievement of cultural authority were the discrediting of a competitive group (the pedologists) and the decimation of the educational bureaucracy by the purges. ${ }^{37}$ This left a vacuum which a living Makarenko was perhaps not suitable to fill (though one should not underestimate the instinctive approval Communists felt for successful self-educated practical men in the cultural field-rabochieizobretateli whose discoveries could confound the academicians). But Makarenko died in 1939, and his name evidently became a rallying point for those who disliked the increasingly formal, academic, and traditional organization of the Soviet school. After a lively discussion of the "Makarenko heritage" in 1939-40 in both the educational and literary professions, Pravda gave editorial endorsement to Makarenko as an educational theorist. ${ }^{38}$ This

35. Peter Juviler, "Revolutionary Law and Order: Crime, Politics and Social Change in the USSR" (unpublished manuscript, chapter 7, pp. 20-21).

36. This characterization of Makarenko's support is based on analysis of articles listed in Letopis shurnal'nykh statei for 1938-40 and on interviews in Moscow. It should be pointed out that among Communists of the cultural-revolution generation, Makarenko had critics as well as supporters-notably the group of former Communist Academy personnel associated with the journal Literaturnyi kritik.

37. The pedologists' fall came with the Central Committee resolution of July 4, 1936, "On pedological distortions in the system of the education commissariats," in $D i$ rektivy $V K P(b)$ i postanovleniia sovetskogo pravitcl'stva o narodnom obrazovanii, vol. 1, p. $190 \mathrm{ff}$. The educational bureaucracy was found to contain a "counterrevolutionary Narkompros center" headed by the commissar of education of the RSFSR, A. S. Bubnov, and his deputy, M. S. Epshtein. On Bubnov's arrest, see A. Binevich and Z. Serebrianskii, Andrei Bubnov (Moscow, 1964), pp. 78-79.

38. Pravda, August 27, 1940, cited in Morozova, A. S. Makarenko, p. 29. 
may have constituted leadership intervention, although it is notable that the endorsement was not followed by any change in practical education policy. The alternative possibility is that Pravda did not prejudge the issue but settled for what emerged as a majority opinion among professional educational theorists.

In the postwar period, the orthodoxies already established held their positions, with Makarenko-who may be seen as achieving probationary status in 1940-rising to the full status of cultural authority around $1950 .^{39}$ The important development of these years was the creation of cultural authorities in the natural sciences. Of these, the late "bourgeois" physiologist Pavlov was closest to the Gorky model. Pavlov, an outspoken critic of the Communists during the 1920 s, when he was already a scientist of international reputation, was acclaimed and honored in the Soviet Union in the years before his death in 1936 but remained non- and probably anti-Communist. According to Boris Nicolaevsky, Bukharin spoke, in the mid1930s, of consulting with Gorky and Pavlov on the possible creation of an "intelligentsia party" which would give expert advice to the Soviet government. ${ }^{40}$ In 1950, apparently by decision of the party leadership (which the scientific community took as an affront), Pavlov became a cultural authority, and an unchallengeable system was created in his name. ${ }^{41}$

Another more notorious postwar example was that of Lysenko, ${ }^{42}$ and his case inevitably raises the question of whether the party leadership's attitude to professional values and kul'turnost' had changed. However great the scientists' objection to a "Pavlovian orthodoxy," Pavlov himself had been highly respected. Lysenko was not respected, and his establishment as a cultural authority outraged the scientists. It was the climax of a long campaign waged by Lysenko (a nonparty man) and his supporters for official and scholarly recognition. In the 1930s, the factors in Lysenko's favor had been the panaceas he offered in an area-agricultural science-where they were desperately needed. He presented an image of homespun practicality which appealed to Communists who believed in science but were suspicious of intellectuals; and, like Makarenko, he was good copy for Soviet journalists. Against him had been the party leadership's strong commitment to support the scientific establishment, and the scientists' refusal to give him professional acceptance. Stalin's "Bravo, comrade Lysenko!" in $1935^{43}$ did not

39. See Morozova, A. S. Makarcnko, p. 45.

40. Boris Nicolaevsky, Pozver and the Sovict Elite (New York, 1965), pp. 14-15.

41. Loren R. Graham, Science and Philosophy in the Soviet Union (New York: Alfred A. Knopf, 1972), p. 375.

42. On Lysenko, see David Joravsky, The Lysenko Affair (Cambridge, Mass.: Harvard University Press, 1970); and Zhores A. Medvedev, The Rise and Fall of T. D. Lyscnko, trans. I. Michael Lerner (New York: Columbia University Press, 1969).

43. Joravsky, The Lysenko Affair, p. 83. 
make Lysenko a cultural authority, though it brought him closer; neither did the purges, despite the repression of some of his academic opponents.

What then had changed by 1948? The first possibility is that Lysenko's appeal to the leadership had increased; the second, that the leadership's respect for professional opinion had diminished; the third, that the scientists had become less vehement in their opposition. There is some evidence for all these hypotheses. It was a time of postwar exhaustion, cultural stagnation stirred only by random bursts of aggression from the leadership, rigidity and inflexibility at the top, and, on Stalin's part, a weakening grasp of reality and increasing paranoia. Dynamic transformation was not part of the reality of postwar Russia, but it was, perhaps for this very reason, an obsessive theme in the rhetoric. Stalin's unsuccessful reforestation campaign (celebrated in art by Leonov's novel, The Forest, and Shostakovich's Song of the Forests, and enthusiastically supported by Lysenko) was meant to show Soviet mastery over nature. Similar points were being made in official commendation of Soviet scientific achievements, among them Lysenko's mutations, Pavlov's conditioned reflexes, and Olga Lepeshinskaia's experiments with the creation of living cells. ${ }^{44}$ Lysenko's appeal had therefore increased because he provided evidence of the natur-transforming powers in which the leadership wanted to believe.

In the years immediately preceding Lysenko's success, the leadership had been engaged in a disciplinary operation against the cultural intelligentsia-the zhdanovshchina. A range of eminent cultural figures of all types, from the Communist phulosopher Alexandrov to the apolitical composers Shostakovich and Prokofiev, had been subjected to sudden violent abuse from the party leader A. A. Zhdanov. ${ }^{45}$ This undoubtedly influenced the scientists' behavior when the pressure turned on them, especially since they had lost their most distinguished and diplomatic anti-Lysenko negotiator, Academician Nikolai Vavilov, through his arrest in $1940 .{ }^{46}$

But, taking into account an evident suspension of respect for professional values on the part of the leadership, we still have to decide whether this indicated a basic change of the previous orientation. The zhdanovshchina caused panic among the intelligentsia, and it was accompanied by the so-called

44. Lepeshinskaia was an old Bolshevik member of the prerevolutionary emigration and one of the first Communists to be appointed (against bitter faculty and student protest) to the medical school of Moscow University at the beginning of the $1920 \mathrm{~s}$. On her work as a cytologist in the 1940s, see Graham, Science and Philosophy in the Soviet Union, p. 276.

45. Extensive quotations from the decrees and official statements on culture in this period are given in George S. Counts and Nucia Lodge, The Country of the Blind: The Soviet System of Mind Control (Boston: Houghton Mifflin, 1949). For a stenographic report of Zhdanov's meeting with composers in 1948, see A. Werth, Musical Uproar in Moscow (London: Turnpike Press, [1949]).

46. Joravsky, The Lysenko Affair, p. 107. 
"anticosmopolitan campaign" which cost the lives and freedom of a number of Jewish intellectuals and of others who had been in close personal contact with foreigners during the war and immediately after. But with the exception of these special categories, the intelligentsia was not facing a threat to its existence or a new cultural revolution. The attacks on leading cultural figures were not followed by arrest and often not even by demotion. There was no attack on the status and privileges of the intelligentsia, except that the privilege of communicating with foreigners was withdrawn. There was no threat of collective replacement, no new pressure on members of the intelligentsia to join the party, and no new impediment to their doing so.

The old cultural orthodoxies remained in force and, as in previous periods of political tension, were observed with particular diligence. Veneration of persons was, in fact, increased by the extravagant blossoming of the Stalin cult-which had its own important impact on the cultural scene, but not at the level of basic party/intelligentsia relations. In his articles on linguistics, Stalin sent out a very ambiguous message attacking the "Arakcheev regime" established in linguistics by disciples of the late Marxist scholar N. Ia. Marr. ${ }^{47}$ Since Stalin took his position from the traditional nonMarxist linguists, he could be seen as defending "bourgeois" professional values. On the other hand, since he attacked "Arakcheev regimes" in scholarship, he could be seen as renouncing the whole institution of cultural authorities. Neither interpretation was easy to reconcile with the contemporary party endorsement of Lysenko and Pavlov, so Stalin's political message, if he had one, sank without trace. At this period it seems that the regime was hardly capable of making major policy initiatives or generating radical structural change. In culture, as elsewhere, it was a time of tense inaction while the political leadership waited for Stalin to die.

Both the Lysenko case and the zhdanorshchina show that the party could on occasion repudiate professional values by falling back on a kind of Communist populism, as if its cultural policy were based on the encouragement of rabochic-izobretateli and aged peasants making folk epics on the life of Stalin. The populist greeting was offered to the cloth-capped and surly Lysenko, to Makarenko, Nikolai Ostrovskii, and the image of the young Gorky tramping Russia in rags; the same spirit was reflected in Zhdanov's advice to the composers in 1948 to learn from the simple folk songs of the people. But it was not dominant in the culture of the Stalin period, because the regime had made the basic decision to put its money on $k u l^{\prime}$ turnost', as Vera Dunham has pointed out, ${ }^{48}$ and to honor the old non-

47. "Marxism and the Question of Linguistics" (first published in Pravda, June 20, 1950 ) in Stalin, Sochincniia, ed. Robert H. McNeal, vol. 3 (16), pp. 114-48. Press.

48. See Vera Dunham, In Stalin's Time, to be published by Cambridge University 
Communist, nonproletarian cultural intelligentsia. In Western discussion, the question kto kogo? has not been asked because the power relationship between party leadership and intelligentsia seems obvious. Yet power and cultural authority were in different hands under Stalin: the party had the political power to discipline the intelligentsia, but lacked the will or resources to deny its cultural authority. In cultural terms, then, who was assimilating whom?

The totalitarian model was created under the impact of postwar developments which struck Western observers as sinister and appalling: imposition of Soviet control in Eastern Europe, which involved the wholesale export of an alien and monolithic "Stalinist culture"; anti-Semitism in Russia particularly directed against the Jewish intelligentsia; and a series of dramatic political interventions in cultural and intellectual life. Interpretation of the Soviet system was based on extrapolation back into the past and forward into the future from this focal point.

When the Soviet Union appeared to move away from "totalitarianism" after Stalin's death, scholars began to doubt both the model and its extrapolation into the past; and there was a reexamination of the early history of the party, the October Revolution, and NEP. But in regard to culture, the effect of this reexamination was to throw the Stalin period into still darker relief in contrast to the brightness of the twenties. Russian memoirs and scholarly works, appearing in the West while this reexamination was in progress, described the suffering of the intelligentsia under Stalinist repression and the purges. Many of the samizdat writers adopted the concept of totalitarianism as part of their indictment of the Soviet system. All this combined to produce a curious situation in Western scholarship. For many scholars, the totalitarian model has been discredited except for the Stalin period, where moral indignation and respect for the witness of participants has led to its retention.

If the memoirs and activity of Soviet dissidents in the 1960s and 1970s heightened the sense, already present in the scholarship, of a David-andGoliath confrontation between intelligentsia and regime in the Stalin period, they also provide support for another view. For what this dissident activity very strikingly demonstrates is that the old Russian intelligentsia maintained its traditions and sense of identity right through the Stalin period. We are now seeing-in the literary memoirists, the dissidents, the groups of young Soviet disciples of Berdiaev, Pasternak, and Akhmatova-the inheritors and the perpetuators of that tradition. We are also seeing the comparative weakness of another tradition, that of the self-consciously Communist and Marxist intelligentsia, represented, for example, by Tvardovsky and Roy Medvedev. 
If this is the legacy of the Stalin period in culture, we have to consider whether an explanation in terms of total repression and absolute party commitment to Communist cultural hegemony is really adequate.

This article has attempted to provide an alternative framework for discussion of culture and politics under Stalin. The conclusions can be summarized as follows. From the early 1930s, the intelligentsia as a whole became a privileged group holding high status in Soviet society. The "bourgeois" cultural intelligentsia was particularly favored by the regime, although few of its members were Communists and their services in practical terms were not indispensable to the state. Within this group, preference went to those with highest professional reputation and strongest commitment to traditional professional values. The Communist intelligentsia-professional iconoclasts, makers of the "cultural revolution," and exponents of "proletarian hegemony" in culture during the First Five-Year Plan periodquickly lost authority, influence, and identity as a group in the 1930s.

The party required conformity from the intelligentsia, and this included acknowledgment of the truth of Marxism-Leninism, the leading role of the party, and Stalin's final authority on all questions. But, having withdrawn support from the Communist intelligentsia and abandoned discrimination on grounds of social origin, the party had chosen to avoid a real ideological confrontation or battle of cultural values with the old "bourgeois" intelligentsia. The conformity which was enforced was, above all, conformity to professional norms established within each profession through a process of negotiation between professionals, cultural bureaucrats, and party leadership. These norms were often based on emulation of a nonparty cultural figure like Gorky, Stanislavsky, or Makarenko.

The party leadership itself accepted many of the cultural values of the intelligentsia, and apolitical kul'turnost' became a mark of status in Soviet society. The regime had absolute power to discipline the intelligentsia-as it did in the zhdanovshchina of the 1940s-and to repress its members. But power to discipline must be distinguished from power (or desire) to create a specifically Communist culture and Communist intelligentsia. An important choice was made in the early thirties, when the Communist cultural revolutionaries were repudiated. By deferring to the cultural authority of the old intelligentsia and bringing its members into the circle of privilege, the party leadership left kto kogo? in culture an open question. 